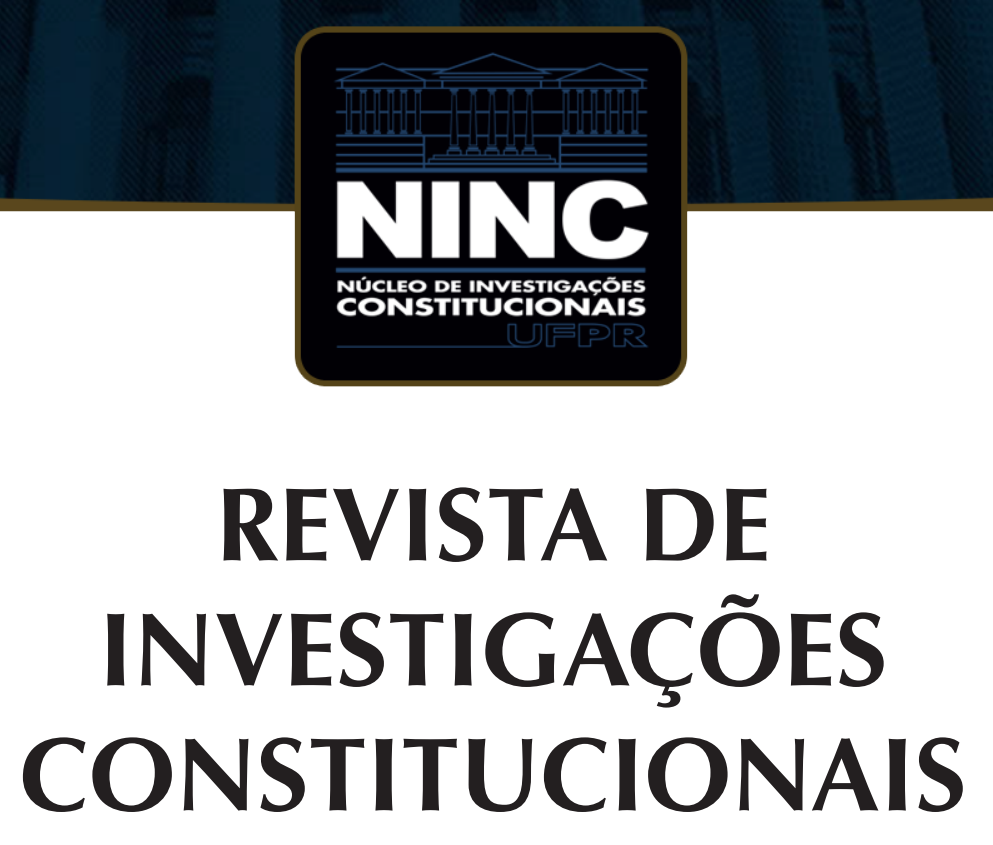

JOURNAL OF CONSTITUTIONAL RESEARCH

vol. 7 | n. 3 | setembro/dezembro 2020 | ISSN 2359-5639 | Periodicidade quadrimestral Curitiba | Núcleo de Investigações Constitucionais da UFPR | www.ninc.com.br 


\title{
Consequencialismo no Supremo Tribunal Federal: uma solução pela não surpresa
}

\section{Consequencialism in Brazilian Federal Supreme Court: a solution through not surprise}

\author{
RODRIGO BRANDÃO I, * \\ ' Universidade do Estado do Rio de Janeiro (Rio de Janeiro, Rio de Janeiro, Brasil) \\ rbrandao2@globo.com \\ https://orcid.org/0000-0002-9663-2066 \\ ANDRÉ FARAH $1, *$ \\ ' Universidade do Estado do Rio de Janeiro (Rio de Janeiro, Rio de Janeiro, Brasil) \\ andre_farah@terra.com.br \\ https://orcid.org/0000-0001-7656-2884 \\ Recebido/Received: 17.02 .2020 / February $17^{\text {th }}, 2020$ \\ Aprovado/Approved: 03.11.2020 / November $11^{\text {th }}, 2020$
}

\section{Resumo}

O artigo pretende apresentar soluções para a forma com que o Supremo Tribunal Federal pratica o consequencialismo, constituindo-se de uma pesquisa do tipo qualitativa, com objetivos descritivo-explicativos e propositivos, utilizando para tal o procedimento de pesquisa bibliográfico. Partindo de uma exposição sobre o pragmatismo, destacam-se o consequencialismo e o empirismo. Para confrontação e crítica, explica-se o significado de consequenciachismo. Após isso, estudam-se casos julgados pelo Supremo Tribunal Federal com a finalidade de construir-se uma linha argumentativa a favor de um valor fundamental de não surpresa. Para tanto, alicerça-se o texto na segurança jurídica e no contraditório. Assim,

\section{Abstract}

The paper intends to show some solutions for the style that the Federal Supreme Court practices the consequencialism, being consisted of a qualitative type research, with descriptive, explanatory and purposeful aims, using the bibliographic search procedure for such. Starting by an exposition about the pragmatism, it highlighted the consequencialism and the empirism. For confrontation and criticize, the meaning about consequencithinkness is explained. After analyzing cases ruled by Federal Supreme Court we intend to build an argument in favor of fundamental value of not surprise. For this, the paper is grounded in legal certainty and contradictory. With this, it started the purposeful part, in which the not surprise aims to try the consequencialism

Como citar esse artigo/How to cite this article: BRANDÃO, Rodrigo; FARAH, André. Consequencialismo no Supremo Tribunal Federal: uma solução pela não surpresa. Revista de Investigações Constitucionais, Curitiba, vol. 7, n. 3, p. 831-858, set./dez. 2020. DOI: $10.5380 /$ rinc.v7i3.71771.

* Professor-Adjunto de Direito Constitucional da Universidade do Estado do Rio de Janeiro (Rio de Janeiro-RJ, Brasil). Doutor e Mestre em Direito Público pela Universidade do Estado do Rio de Janeiro. Procurador do Município do Rio de Janeiro. E-mail: rbrandao2@globo.com.

** Doutorando e Mestre em Direito Público pela Universidade do Estado do Rio de Janeiro (Rio de Janeiro-RJ, Brasil). Promotor de Justiça do Ministério Público do Estado do Rio de Janeiro. E-mail: andre_farah@terra.com.br. 
entra-se na parte propositiva, na qual a não surpresa visa testar o consequencialismo e impedir o consequenciachismo. Com essa intenção, a explicação das propostas divide-se em processo subjetivo e processo objetivo.

Palavras-chave: consequencialismo; Supremo Tribunal Federal; não surpresa; pragmatismo; empirismo. and to prevent the consequencithinkness. And for that, the explanation of the proposals is divided in subjective and objective processes.

Keywords: consequencialism; Federal Supreme Court; not surprise; pragmatism; empirism.

\section{SUMÁRIO}

1. Introdução; 2. O pragmatismo; 2.1. O consequencialismo e o empirismo; 2.2. O problema do consequenciachismo; 2.3. Uma análise de casos do Supremo Tribunal Federal; 2.3.1. O caso do início da execução da pena a partir de decisão condenatória de segundo grau de jurisdição; 2.3.2. O caso do indulto presidencial (governo Michel Temer); 2.3.3. O caso do ensino domiciliar; 3. Um valor fundamental de não surpresa; 3.1. A extração constitucional da segurança jurídica; 3.2. A extração constitucional do contraditório; 4. Proposições; 4.1. A não surpresa como testagem do consequencialismo e contra o consequenciachismo; 4.2. O processo subjetivo; 4.3. O processso objetivo; 5. Considerações finais; 6. Referências.

\section{INTRODUÇÃO}

Em Müller vs Oregon', julgado em 1908, pela Suprema Corte norte americana, Louis D. Brandeis apresentou memorial que possuía apenas duas páginas com conteúdo jurídico e cento e dez outras páginas voltadas para as consequências da longa duração do trabalho em relação à mulher ${ }^{2}$. No caso Webster vs Reproductive Health Services ${ }^{3}$, julgado pela Suprema Corte norte americana em 1989, vinte e cinco senadores, cento e quinze deputados, duzentos e oitenta e um historiadores, oitocentos e oitenta e cinco professores de direito e outros tantos grupos e interessados apresentaram considerações ${ }^{4}$. Esses casos, em comum, significam a grande importância do debate em relação a questões fáticas, ainda que uma questão constitucional esteja sob análise.

Porém, imagine, em um caso concreto, junto ao Supremo Tribunal Federal (STF), que no momento de julgar, seja em decisão monocrática, seja apresentando voto no colegiado, um ministro puxe uma carta, um dado não presente nos autos. Dizendo-se um consequencialista, ou tomando uma conduta como tal, o magistrado afirma ter tido acesso ao referido estudo e o utiliza na decisão ou voto que profere, para lhe dar lastro. Como fica a parte ou a parcela da sociedade afetada por esse dado novo na tutela do

EUA. Suprema Corte, Muller v. Oregon, 208 U.S. 412 (1908).

2 MENDES, Gilmar Ferreira. Jurisdição constitucional: o controle abstrato de normas no Brasil e na Alemanha. 4 ed. São Paulo: Saraiva, 2004, p. 221.

3 EUA. Suprema Corte, Webster v. Reproductive Health Services, 492 U.S. 490 (1989).

4 DWORKIN, Ronald. 0 direito da liberdade: a leitura moral da Constituição norte-americana. Tradução Marcelo Brandão Cipolla; revisão técnica Alberto Alonso Muñoz. São Paulo: Martins Fontes, 2006, p. 68-69. 
seu direito? Ela não tem meios para impugnar esse argumento lastreado no referido estudo? Como fica a controlabilidade do consequencialismo? Caso se trate de consequenciachismo, este não viola um sentido constitucional fundamental?

Os ministros do STF, em diversos casos, nos seus votos e decisões, têm feito uso de investigações empíricas, que antes não se encontravam nos respectivos processos. Algumas vezes citando as fontes, outras vezes sem declinar a origem, os julgadores têm apresentado as mesmas no último momento processual, o decisório, sem que os envolvidos antes pudessem debater sobre as informações desses estudos. Ocorre que, como mais à frente ficará consignado, sobre um mesmo assunto, pesquisas podem apontar evidencias diversas e os ministros estão, então, dando soluções antagônicas entre si.

Com o intuito de refinar o consequencialismo e diminuir as possibilidades de consequenciachismo, este trabalho buscou formatar uma ideia de não surpresa. $\mathrm{O}$ objetivo geral, assim, foi tratar do consequencialismo e do consequenciachismo à luz de um valor constitucional de não surpresa. Para isso, como objetivos específicos os seguintes passos foram trilhados. O pragmatismo, o consequencialismo e o empirismo, o problema do consequenciachismo, além de uma análise de casos do STF foram estudados. Também um valor fundamental de não surpresa, a partir da extração constitucional da segurança jurídica e do contraditório, foi desenvolvido. Com isso, chegou-se à parte propositiva do trabalho, na qual se separou a análise para processos subjetivo e objetivo. $\mathrm{O}$ estudo constituiu-se de uma pesquisa do tipo qualitativa, com objetivos descritivo-explicativos e propositivos, utilizando para tal o procedimento de pesquisa bibliográfico. A hipótese foi que o valor constitucional da não surpresa não recomenda o uso pelos ministros do STF, no momento decisório, de dados empíricos antes desconhecidos no processo, o que gera um refinamento do consequencialismo e um rebaixamento da conduta consequenciachista.

\section{O PRAGMATISMO}

O pragmatismo é um método de solução de questões e, no caso do direito, de questões jurídicas. Ele pode ser concebido como uma teoria de como decidir ou uma teoria de como decidir qual teoria deve ser usada para decidir, ou seja, uma meta teoria. Pela primeira figura, seria uma teoria de primeira ordem, em que suas características se apresentam como solucionadoras do caso em análise. Já pela segunda figura, como teoria de segunda ordem, seus predicados são utilizados para resolver qual a teoria de primeira ordem deve ser posta em prática para determinada situação.

Imbuída na ideia de pragmatismo está a de antifundacionalismo. O fundacionalista almeja o encontro da fundação. Significa uma busca para trás na procura de um começo, de um início. O antifundacionalismo, no entanto, significa a ausência desse ponto de parada e a constante produção de novas investigações. Nega uma fundação 
estática, perpétua e imutável de um pensamento ${ }^{5}$. A realidade, nessa lógica, seria independente das opiniões das pessoas individualmente consideradas, havendo uma nota de falibilidade no $\mathrm{ar}^{6}$, o que propulsionaria o esforço pela descoberta.

Também o contextualismo é característica do pragmatismo. Seria isso a importância do papel do contexto no desenvolvimento das investigações ${ }^{7}$, sem se ignorar, porém, que a realidade é mutante. As mudanças geram uma nova versão da verdade, que exige uma adequação contínua ${ }^{8}$. Paralelo a isso, diz-se que um olhar para o futuro, sem uma necessária consistência com o passado é uma marca do pragmatismo9. Para Posner, o pragmatismo faz uso crítico da história e observa que casos genuinamente novos não são adequadamente resolvidos através de precedentes e das leis ${ }^{10}$.

É possível igualmente apontar para outro aspecto do pragmatismo. Na tomada de decisão, o pragmatismo pede que o juiz não olhe tão somente seu caso concreto. Reclama uma visão mais ampla, que leve em consideração o mundo fora da situação em análise. A atenção volta-se para os efeitos sistêmicos da decisão ${ }^{11}$. Logo, as consequências não são avaliadas apenas para dentro de um processo. Tem uma conotação maior e exige que se busque aquilatar tais efeitos para fora do caso em exame ${ }^{12}$.

O consequencialismo, que pode ser visto como um juízo de "prováveis efeitos concretos de diferentes normas"13, para aferição de compatibilidade ou não de uma solução com a ordem constitucional, será destacado e estudado no próximo subitem. Junto com ele, o empirismo, até mesmo como rejeição a certa filosofia ${ }^{14}$, será compreendido.

5 POGREBINSCHI, Thamy. Pragmatismo: teoria social e política. Rio de Janeiro: Relume Dumará, 2005, p. 26. POGREBINSCHI, Thamy. Pragmatismo: teoria social e política. Rio de Janeiro: Relume Dumará, 2005, p. 29. POGREBINSCHI, Thamy. Pragmatismo: teoria social e política. Rio de Janeiro: Relume Dumará, 2005, p. 49. 8 POGREBINSCHI, Thamy. Pragmatismo: teoria social e política. Rio de Janeiro: Relume Dumará, 2005, p. 56-57.

9 ARGUELHES, Diego Werneck; LEAL, Fernando. Pragmatismo como [Meta] Teoria da Decisão Judicial: Caracterização, Estratégias e Implicações. In: SARMENTO, Daniel (coord.). Filosofia e Teoria Constitucional Contemporânea. Rio de Janeiro: Lumen Juris, 2009, p. 187.

10 POSNER, Richard A. Law, pragmatism, and democracy. Cambridge, Massachusetts; London, England: Harvard University Press, 2003, p. 71-72.

11 ARGUELHES, Diego Werneck; LEAL, Fernando. Pragmatismo como [Meta] Teoria da Decisão Judicial: Caracterização, Estratégias e Implicações. In: SARMENTO, Daniel (coord.). Filosofia e Teoria Constitucional Contemporânea. Rio de Janeiro: Lumen Juris, 2009, p. 186.

12 POSNER, Richard A. Law, pragmatism, and democracy. Cambridge, Massachusetts; London, England: Harvard University Press, 2003, p. 59.

13 PARGENDLER, Mariana; SALAMA, Bruno Meyerhof. Direito e consequência no Brasil: em busca de um discurso sobre o método. Revista de Direito Administrativo, Rio de Janeiro, v. 262, p. 95-144, jan./abr. 2013, p. 126.

14 ARGUELHES, Diego Werneck; LEAL, Fernando. Pragmatismo como [Meta] Teoria da Decisão Judicial: Caracterização, Estratégias e Implicações. In: SARMENTO, Daniel (coord.). Filosofia e Teoria Constitucional Contemporânea. Rio de Janeiro: Lumen Juris, 2009, p. 187. 
Dentre suas características, portanto, o pragmatismo busca olhar para frente, tendo uma visão crítica da história; preza pelo empirismo e foca em algum tipo de análise do que pode acontecer se tomada a decisão em um certo sentido (relação causa e efeito).

\subsection{O consequencialismo e o empirismo}

Com o passar do tempo e até como resultado de uma lapidação da inteligência, a pesquisa acadêmica se tornou mais e mais científica. Para Pargendler e Salama, tal se deu, dentre algumas razões, por causa da colocação do Poder Judiciário no centro do arranjo político e devido à aplicação de princípios e a consequente necessidade de utilização da proporcionalidade. Por esta, os resultados da operacionalização dos seus subprincípios devem ser aferidos por dados empíricos ou juízos probabilísticos ${ }^{15}$. Assim, não é errado dizer que o consequencialismo jurídico é um programa teórico que condiciona a adequação jurídica de uma decisão à valoração das consequências relacionadas à mesma e às suas alternativas. Pode, nesta explicação, haver um consequencialismo forte e um consequencialismo fraco. No primeiro existiria uma prioridade ou exclusividade na valoração das consequências, no juízo de adequação de uma determinada decisão. O segundo, no entanto, traria a marca de igualdade de peso quando comparados argumentos com valoração das consequências e os não consequencialistas ${ }^{16}$.

Assim, o consequencialismo jurídico é uma "postura, interpretativa ou cognitiva, tendente a considerar as consequências de ato, teoria ou conceito", pelo qual a decisão que o acolher deverá fundamentadamente apresentar as respectivas consequências jurídicas. Estas, por sua vez, são estados imediatos ou imediatamente futuros e devem ser identificadas na respectiva decisão ${ }^{17}$.

A consequência inerente à ideia de consequencialismo, como parece evidente, traz em si um sentido de empirismo. Se o que se almeja é ter algum olhar para frente e, de algum modo, alcançar um resultado a partir de determinada decisão, não é concedido fazer esta operação sem um suporte com algum grau de segurança. É por isso que aqui se junta a compreensão de empirismo. Para se evitar que se confundam

\footnotetext{
15 PARGENDLER, Mariana; SALAMA, Bruno Meyerhof. Direito e consequência no Brasil: em busca de um discurso sobre o método. Revista de Direito Administrativo, Rio de Janeiro, v. 262, p. 95-144, jan./abr. 2013 , p. 109-119.

16 SCHUARTZ, Luis Fernando. Consequencialismo jurídico, racionalidade decisória e malandragem. Revista de Direito Administrativo, Atlas, p. 130-158, 2008, p. 130-131.

17 DE MENDONÇA, José Vicente Santos. Art. 21 da LINDB - Indicando consequências e regularizando atos e negócios. Revista de Direito Administrativo, Rio de Janeiro, Edição especial: Direito Público na Lei de Introdução às Normas de Direito Brasileiro - LINDB (Lei n 13.655/2018), p. 43-61, nov. 2018, p. 47-49.
} 
consequência e palpite, a decisão consequencialista deve pautar-se em uma "base, lógica ou empírica, de evidenciação" ${ }^{\prime 18}$.

O problema é que o mau emprego do consequencialismo pode transformar-se em consequenciachismo. O uso pouco metódico de investigações empíricas, não raro, leva a soluções mais subjetivas do que objetivas. É sobre consequenciachismo que a próxima subseção trata.

\subsection{O problema do consequenciachismo}

Como visto acima, duas das marcas do pragmatismo são o consequencialismo e o empirismo. Olhando para frente e levando em consideração não apenas o caso que existe em concreto nas mãos, é preciso que, a partir das decisões a serem tomadas, observem-se os prováveis efeitos que advirão.

Para que esse exercício não fique sem uma base na qual se fundamente, a decisão mencionada deve estar lastreada em dados. Tais dados parecem ter dois focos muito semelhantes: referem-se a algo passado ou presente para ajudar na tomada de decisão e possibilitam olhar para frente, a fim de indicar que uma decisão em certo sentido deve ocorrer, porque há um dado indicativo para tanto.

É decorrência lógica do consequencialismo o empirismo. Todo esse desenho exige uma ancoragem em dados empíricos, em pesquisas que tornem viável entender qual caminho percorrer na questão em análise. Não se vislumbra como corretamente exercitar um raciocínio de consequências sem a presença de um estudo concreto sobre determinada situação. Se uma decisão precisa de um móvel, para um lugar, este móvel e a indicação desse lugar precisam estar, de alguma forma, abrangidos por uma investigação.

O problema é a dificuldade em fazer isso, no sentido de se evitarem subjetivismos e de empregar corretamente os dados na tentativa de construir uma decisão adequada. Não à toa, Conrado Hübner Mendes, chamando a atenção para isso, critica o atuar judicial. Conrado considera que o consequencialismo "busca detectar relações empíricas de causa e efeito, pratica a dúvida metódica, vai atrás de pesquisas e dialoga com as ciências sociais", o que é diferente do consequenciachismo, "um estado de espírito, um pensamento desejoso ('wishful thinking'), a confusão entre o que é e o que se queria que fosse". O consequenciachista, então, profere mais palpites, intuições e argumentos com baixo teor empírico ${ }^{19}$.

\footnotetext{
18 DE MENDONÇA, José Vicente Santos. Art. 21 da LINDB - Indicando consequências e regularizando atos e negócios. Revista de Direito Administrativo, Rio de Janeiro, Edição especial: Direito Público na Lei de Introdução às Normas de Direito Brasileiro - LINDB (Lei no 13.655/2018), p. 43-61, nov. 2018, p. 50.

19 MENDES, Conrado Hübner. Jurisprudência impressionista. Época, 14 set. 2018. Disponível em: <https:// epoca.globo.com/conrado-hubner-mendes/jurisprudencia-impressionista-23066592>. Acesso em: 21 jul. 2019.
} 
Esse é um assunto relevante e alvo de mais críticas, justamente porque perceptível o exercício de um consequencialismo sem método ou rigor, um consequencialismo inconsequente, a reclamar uma virada com a prática da dúvida sistemática com rigor inclemente ${ }^{20}$. Nesse ponto, Daniel Wang diz que o consequenciachismo tenta aquilatar "o impacto do Direito na realidade por meio do uso pouco cuidadoso de dados empíricos (sem avaliar fontes, métodos, escopos, incertezas e objeções)", caracterizando-se "por apresentar como fato meras especulações e intuições sobre a realidade social, política e econômica". O consequenciachista, por causa das falhas citadas, acaba que explicita sua preferência pessoal, sem uma preocupação maior com o mundo real ${ }^{21}$.

Se as críticas são pertinentes, não se ignoram as dificuldades argumentativas do consequencialismo. No plano normativo, a valoração de consequências deve ser conhecida, operacionalizável, em um sentido estável no tempo, e possuir uma metodologia a justificar a prioridade de um critério sobre o outro. Já no plano positivo, o olhar para frente pode enfrentar uma distinção entre o "futuro imaginado agora" e o "futuro que realmente chegará". Mas, é por todas essas dificuldades que se faz necessário um rigor de diagnóstico confiável ${ }^{22}$.

Chega-se, portanto, a uma conclusão provisória. Na prática, talvez exercitar o consequencialismo seja realmente difícil, o que acaba permitindo que se escorregue para o consequenciachismo. Este, entretanto, é falseável, já que permite a demonstração de que o tomador de decisão errou. É este o ponto importante para o presente trabalho, como será desenvolvido mais à frente.

\subsection{Uma análise de casos do Supremo Tribunal Federal}

Na presente subseção, serão analisados alguns casos em que o STF vestiu uma roupagem consequencialista. Não será dito se o mérito foi corretamente julgado. $\mathrm{O}$ que se pretende é verificar como a Corte faz uso dos dados em seus julgamentos. No final, deseja-se checar se o Tribunal esclarece quais são os estudos, a metodologia, os autores, as conclusões e onde estão disponíveis para acesso, assim como se as partes têm oportunidade de estudar previamente os dados e apresentar argumentos e outros dados em sentido contrário.

20 DE MENDONÇA, José Vicente Santos. Em defesa do consequenciachismo. Direito do Estado, ano 2018, 16 set. 2018, no 413. Disponível em: <http://www.direitodoestado.com.br/colunistas/jose-vicente-santos-mendonca/em-defesa-do-consequenciachismo>. Acesso em: 21 jul. 2019.

21 WANG, Daniel Wei Liang. Entre o consequenciachismo e o principiachismo, fico com a deferência. Jota, 20 set. 2018. Disponível em: < https://www.jota.info/paywall?redirect_to=//www.jota.info/opiniao-e-analise/ artigos/entre-o-consequenciachismo-e-o-principiachismo-fico-com-a-deferencia-20092018>. Acesso em: 21 jul. 2019.

22 LEAL, Fernando. Consequenciachismo, principialismo e deferência: limpando o terreno. Jota, 01 out. 2018. Disponível em: <https://www.jota.info/paywall?redirect_to=//www.jota.info/stf/supra/consequenciachismo-principialismo-e-deferencia-limpando-o-terreno-01102018 >. Acesso em: 21 jul. 2019. 


\subsubsection{O caso do início da execução da pena a partir de decisão condenatória de segundo} grau de jurisdição

O debate a respeito da execução da pena em segundo grau de jurisdição foi, dentre outros momentos, realizado no Habeas Corpus (HC) no 126.292/SP23 quando foi denegada a ordem, por maioria. É interessante notar que o ministro Luís Roberto Barroso abriu uma parte, a terceira de seu voto, para expor fundamentos pragmáticos. Elencou duas características: o contextualismo e o consequencialismo. Após passar por diversos tipos de argumentação, expressou, com base em pesquisas da época, que menos de 1,5\% foi o quantitativo de recursos extraordinários providos em favor do réu; que, de 2009 a 19 de abril de 2016, menos 0,1\% das decisões foram absolutórias, no tocante a recursos criminais no STF; e que era massiva a quantidade de casos com prescrição da pretensão punitiva, gerando sensação de descrédito na justiça penal. $\mathrm{O}$ julgador aduziu ser regra, nos diversos países, que o início da execução da pena ou é a decisão de primeiro grau ou a de segundo. Disse ainda que a postura anterior da Corte estimulou a interposição de recursos protelatórios e reforçou a seletividade do sistema penal, ante a impossibilidade de o pobre arcar com tais recursos.

O ministro Celso de Mello, utilizando-se de dados estatísticos do portal da Corte, seguiu direção oposta, em favor da concessão da ordem. Quanto aos números, apontou que de 2006 a 2008, 25,2\% e 3,3\% dos recursos extraordinários criminais foram providos, no todo e em parte, respectivamente, pelo STF. No mesmo sentido e para defender a impossibilidade da execução da pena em segunda instância, o ministro Ricardo Lewandowski disse que o Brasil, à época, tinha a quarta população carcerária, ficando atrás de Estados Unidos, China e Rússia. Disse, ainda, que existiam 600 mil presos e que $40 \%$ desses eram provisórios.

Pela utilização de dados levada a efeito pelos ministros supra, verificou-se que o ministro Barroso teve grande preocupação em apontar os respectivos estudos e seus autores. Já o ministro Celso de Mello teve preocupação ainda mais intensa, enquanto ministro Ricardo Lewandowski não apontou os estudos nos quais se baseara. A metodologia e eventuais conclusões, porém, não foram abordadas pelos julgadores. Também, ao que tudo indica, as partes não tiveram oportunidade de estudar previamente os citados dados, passando despercebida esta preocupação.

\subsubsection{O caso do indulto presidencial (governo Michel Temer)}

A Ação Direta de Inconstitucionalidade (ADI) no 5.874/DF debateu os limites constitucionais à concessão de indulto em caráter geral pelo Presidente da República.

23 BRASIL. STF, HC 126.292/SP - São Paulo; Habeas Corpus; Relator: Min. Teori Zavascki; Julgamento: 17/02/2016; Órgão julgador: Tribunal Pleno; Publicação Processo Eletrônico DJe-100 Divulg 16-05-2016 Public 17-05-2016. 
Em seu pedido, a Procuradoria-Geral da República (PGR) argumentou que o Decreto n० 9.246/2017 concedeu indulto natalino e comutação de penas a condenados que cumpriram frações ínfimas da pena, ou que já foram beneficiados pela legislação e não estavam encarcerados, à pena de multa e a casos ainda não julgados definitivamente. Isso violaria a proibição do Poder Executivo legislar sobre matéria penal, a separação dos Poderes, a individualização da pena e a proibição à proteção insuficiente. Na decisão que concedeu a medida cautelar ${ }^{24}$, o ministro Luís Roberto Barroso destacou que o poder presidencial de perdoar penas não pode ser ilimitado e deve se pautar pelo desenho feito pelo legislador, dizendo que "uma compreensão sistêmica da realidade jurídica e dos efeitos concretos gerados pela aplicação das normas possibilitará um debate público qualificado sobre o tema". Após analisar institutos legais de direito penal, o ministro afirmou a existência de centenas de milhares de mandados de prisão à espera de cumprimento, para assegurar que o sistema de execução penal brasileiro é menos severo do que o de outros países.

A partir daí, números foram inseridos na decisão de concessão da medida cautelar. Foi dito que o Brasil é a terceira maior população carcerária do mundo, com mais de 720 mil presos, em condições degradantes. Adicionou que mais da metade dos encarcerados são acusados ou condenados por crimes não violentos e que 0,25\% são de detentos por prática de delitos contra a administração pública. Além disso, a decisão expôs que $40 \%$ dos presos são provisórios, maioria derivada de flagrante por tráfico de drogas, e $60 \%$ são analfabetos ou não completaram o ensino fundamental.

Após esses números, a decisão partiu para uma análise rápida da leniência com o delito de "colarinho branco" e uma explicação sobre o indulto. Aqui, apontou que informações de Tribunais de Justiça de cinco estados da federação constataram que, entre 2013 e 2017, foram concedidos 27.681 indultos. Tudo isso e mais inúmeros outros argumentos, sobretudo de conotação constitucional, serviram, para ao final, o ministro Barroso deferir a medida cautelar na extensão que entendeu adequada para suspender do âmbito de incidência do decreto sob análise, os crimes de peculato, concussão, corrupção passiva, corrupção ativa, tráfico de influência, os praticados contra o sistema financeiro nacional, os previstos na Lei de Licitações, os crimes de lavagem de dinheiro e ocultação de bens, os previstos na Lei de Organizações Criminosas e a associação criminosa.

A decisão monocrática analisou de maneira criteriosa e densa a questão, porém, no que se refere aos dados empíricos citados, não explicitou o local de publicação dos respectivos estudos, a sua metodologia, autores e conclusões e onde estão disponíveis para acesso. Ademais, tudo aponta no sentido de que as partes não tiveram

24 BRASIL. STF, ADI 5.874 MC/DF - Distrito Federal; Medida Cautelar na Ação Direta de Inconstitucionalidade; Relator: Min. Roberto Barroso; Julgamento: 12/03/2018; Publicação Processo Eletrônico DJE-049 Divulg 13/03/2018 Public 14/03/2018. 
oportunidade de estudar previamente - já que se tratava de deferimento de cautelar - os dados e apresentar argumentos e outros dados em sentido contrário, antes mesmo da apontada decisão. Todavia, frise-se, alguns amici curiae foram admitidos.

\subsubsection{O caso do ensino domiciliar}

No Recurso Extraordinário (RE) no $888.815 / \mathrm{RS}^{25}$, o STF enfrentou a questão da juridicidade do ensino domiciliar. Na origem, tratava-se de mandado de segurança impetrado contra ato da Secretaria Municipal de Educação de Canela/RS que impediu a educação domiciliar a um menor e recomendou a imediata matrícula na rede regular de ensino. Ao ascender à Corte, esta, por enxergar o dever de solidariedade entre a família e o Estado na formação educacional das crianças, jovens e adolescentes, por maioria, julgou inconstitucionais as espécies de unschooling radical - desescolarização radical -, unschooling moderado - desescolarização moderada -, e homeschooling puro. Entendeu que o ensino domiciliar não é um direito público subjetivo e que sua criação dependia de lei federal editada pelo Congresso Nacional.

O ministro Luís Roberto Barroso, relator e vencido, partiu de três pré-compreensões para dar sua solução. Uma, o Estado brasileiro é grande, ineficiente e pratica políticas públicas inadequadas e sem monitoramento. Dois, os resultados de 2017 da Prova Brasil, integrante do Sistema Nacional de Avaliação da Educação Básica, que teriam sido divulgados na semana em que se proferiu o presente julgamento, apontaram que $5 \%$ e $1,7 \%$ dos alunos se situaram na faixa adequada nos testes de matemática e português, respectivamente. E três, sua preferência, em regra, à autonomia e à emancipação das pessoas do que ao paternalismo estatal.

Dentre os sete motivos para pais e responsáveis optarem pela escolarização domiciliar, o relator apontou a proteção da integridade física e mental dos educandos, retirando-os de ambientes escolares agressivos, incapacitantes ou limitadores; o descontentamento com a real eficácia do sistema escolar ofertado pela rede pública ou privada; e a dificuldade de acesso às instituições de ensino tradicionais em virtude de restrições financeiras ou geográficas. Além disso, afirmou o ministro Barroso que fez um levantamento e constatou o crescimento, sobretudo em países desenvolvidos, da população praticante da educação doméstica familiar. Assim, apontou que no Reino Unido o número seria de 100 mil educandos; no Canadá, 95 mil; na Austrália, 55 mil famílias; na Nova Zelândia, 6 mil; na França e Taiwan, 500; nos Estados Unidos, segundo o Departamento de Educação, em 2012, o número era de 1,8 milhão de crianças e adolescentes. Frisou que no Brasil inexiste estatística oficial.

25 BRASIL. STF, RE 888.815/RS - Rio Grande do Sul; Recurso Extraordinário; Relator: Min. Roberto Barroso; Relator p/ Acórdão: Min. Alexandre de Moraes; Julgamento: 12/09/2018; Órgão julgador:Tribunal Pleno; Publicação Processo Eletrônico DJE-055 Divulg 20-03-2019 Public 21-03-2019. 
Disse ainda, ao debater o tema da socialização das crianças e adolescentes em ensino domiciliar, que “(...) conforme pesquisas empíricas relevantes - e as quais eu tive acesso -, elas não apenas têm melhor desempenho acadêmico, o que é indisputado, como também apresentam um nível elevado de socialização, acima da média". O julgador acrescentou que "por circunstâncias diversas, (...) a verdade é que pesquisas empíricas realizadas predominantemente nos Estados Unidos documentam que não há problemas de socialização com as crianças que se encontram no ensino domiciliar".

Assim, por argumentos constitucionais, aliados aos acima aludidos e ainda outros, o ministro Barroso entendeu pela legitimidade do ensino domiciliar, em conformidade com os parâmetros por ele fixados no voto, ainda que tenha admitido uma regulamentação estatal. É de se frisar que muitos dos dados empíricos citados vieram com referências aos respectivos estudos.

No mesmo julgamento, o redator para o acórdão, o ministro Alexandre de Moraes, para dar lastro à sua posição, em determinado momento, fez uso de argumento empírico, ao afirmar que "o Brasil tem a terceira maior taxa de evasão escolar entre cem países", explicando que "o PNUD [Programa das Nações Unidas para o Desenvolvimento] trouxe esse problema". Esclareceu que em vinte anos, o Brasil reduziu a taxa de analfabetismo de $65 \%$ para $16 \%$. E falou que nos Estados Unidos a questão do homeschooling tem ligação com a liberdade religiosa, já que $75 \%$ são mórmons. Isso aliado a outros argumentos, inclusive de ordem constitucional, levou o julgador a entender pela inexistência de um direito público subjetivo de ensino domiciliar e pela necessidade, para viabilizar esta espécie de ensino, de lei proveniente do Congresso Nacional.

Igualmente, para dar lastro aos seus argumentos e afirmar a inconstitucionalidade do ensino domiciliar, o ministro Luiz Fux pautou-se em "[d]ados oficiais sobre abuso sexual infantil", dizendo que "24,1\% dos agressores das crianças são os próprios pais ou padrastos, e 32,2\% são amigos ou conhecidos da vítima". Isso apontaria para o profissional da educação como o mais capacitado a realizar a respectiva função.

O ministro Gilmar Mendes votou pelo desprovimento do recurso. Apontando sua fonte, o Programme for International Student Assessment (PISA), afirmou que, compulsando a edição de 2015, foi possível concluir que o homeschooling não resultou em qualquer ganho para o desempenho da educação no ranking entre os países. Os Estados Unidos e Portugal, permissivos a tal prática, ocuparam a $25^{\mathrm{a}}$ e a $23^{\mathrm{a}}$ colocações. A Suécia que admite apenas por exceção ficou na $28^{a}$ posição, enquanto a Alemanha, que a proíbe, ficou na $16^{\mathrm{a}}$ posição.

Também o ministro Marco Aurélio, para fundamentar seu pensamento, usou de argumentos constitucionais e de dados. Indicando sua fonte, o Instituto Brasileiro de Geografia e Estatística (IBGE), especificamente a Pesquisa Nacional por Amostragem de Domicílios (PNAD) datada de 2015, alertou que 97,7\% dos que possuem 6 e 14 anos estavam matriculados no ensino fundamental. Enfatizou que apenas $76 \%$ dos estudantes 
encerraram o ensino fundamental no momento adequado, que cerca de 2,5 milhões de jovens entre 4 e 17 anos estavam fora da escola e que, destes, cerca de 1,5 milhão eram para estar no ensino médio. Ao final, votou pelo desprovimento do recurso.

Em relação a muitos dos dados acima utilizados, sobretudo os citados pelos ministros Barroso, Gilmar Mendes e Marco Aurélio, foram assinalados os respectivos estudos e os autores, mas não a metodologia e as conclusões. Ademais, não há notícia de que as partes não tiveram oportunidade de estudá-los previamente, apesar de alguns amici curiae terem sido admitidos. Apesar disso, o que chama bastante atenção é o fato de sobre a mesma questão, poderem, em tese, como o STF comprovou neste caso, ser utilizados dados empíricos que direcionaram a soluções antagônicas.

Frente ao espaço possível que este trabalho abriu, para analisar como o empirismo é concretizado pelo STF, ao menos nos apontados casos, algumas conclusões provisórias são autorizadas. Em primeiro, há ministros mais abertos do que outros ao emprego de elementos empíricos para fundamentar as suas decisões. Dos que o fazem, não há um padrão sobre como fundamentar uma decisão ou voto com o uso de dados empíricos. Os estudos e seus autores podem até, mas não sempre, ser citados, porém, a metodologia, as conclusões e como acessá-los não o são frequentemente. Além disso, é rara a preocupação em conferir às partes, a oportunidade de se pronunciar sobre dados e estudos empíricos reputados relevantes anteriormente à prolação da decisão, inclusive em hipóteses de reversão de jurisprudência.

Expressadas as características do pragmatismo, entregando especial atenção ao consequencialismo e ao empirismo, este trabalho demonstrou preocupação em se evitar o consequenciachismo. Após defini-lo, analisou três casos importantes que o STF julgou. Em relação a estes, ficou constatada uma variação grande em como os integrantes da Corte fazem uso de investigações empíricas. Isso revela um estágio embrionário no emprego de dados empíricos como razões de decidir, devendo haver maior cuidado em oportunizar às partes do processo a possibilidade de manifestação sobre o seu teor antes da prolação da decisão. Em defesa da necessidade de não se autorizar o uso surpresa desses estudos pelo STF, é que na próxima seção sustentaremos a necessidade de se evitar o "uso surpresa" desses estudos, em proteção ao princípio constitucional da segurança jurídica e seus corolários.

\section{UM VALOR FUNDAMENTAL DE NÃO SURPRESA}

A seção anterior deste trabalho trouxe uma constatação problemática. O pragmatismo e suas características de cunho consequencialista e empírica não são de fácil execução na prática. Apesar disso, o STF vem decidindo alguns casos com argumentos pragmáticos. Uma grande dificuldade ficou atestada ao final da subseção anterior. Os ministros, cada um ao seu modo, às vezes sem mesmo dizer de onde extraíram 
determinado dado empírico, dão cor aos seus fundamentos constitucionais. Demonstram, no entanto, baixa preocupação com a parte do processo ou parcela da sociedade afetada com o uso da pesquisa que, muitas vezes, podem nem ter conhecimento prévio sobre a existência.

A partir desse olhar, a presente seção buscará formatar a configuração de um valor fundamental de não surpresa. O tema parece mais complexo do que simplesmente repetir o brocardo da mihi factum, dabo tibi ius. Dizer o direito fundado na narrativa de um fato talvez não signifique afirmar que o julgador pode, por si, promover a busca de dados empíricos, para defender sua visão decisória. E, ainda que se pense que pode, permitir que um ministro do STF assim aja, sem franquear, de algum modo, aos afetados pela decisão estudar a pesquisa e eventualmente apresentar outra, em sentido diverso, antes da definição do caso, soa contrário a uma ideia de não surpresa.

\subsection{A extração constitucional da segurança jurídica}

A segurança é fator de relevância ímpar em qualquer área das relações humanas ${ }^{26}$. Não é possível pensar até mesmo na concepção de coletividade se não houver, em um grau mínimo, segurança nas referidas relações. A economia e suas transações reclamam segurança. A política deve acontecer em um ambiente de segurança. E o direito não pode fugir da ideia de segurança.

O princípio da segurança jurídica é uma decorrência do Estado de Direito ${ }^{27}$. Seja enxergando-o como fundamento ${ }^{28}$, como elemento ${ }^{29}$, como razão de ser $^{30}$ ou mesmo como subprincípio ${ }^{31}$ do Estado de Direito, a lógica para o presente trabalho é que o Estado limitado pela ordem jurídica ${ }^{32}$ deve agir em respeito a uma segurança dirigida para o administrado, o cidadão, o jurisdicionado. E com isso, a segurança é voltada

\footnotetext{
26 MELO, Lígia Maria Silva de. Segurança jurídica: fundamento do Estado de Direito. Revista de Direito Administrativo \& Constitucional, Belo Horizonte, ano 6, n. 25, p. 133-144, jul./set. 2006, p. 133.

27 MENDES, Gilmar Ferreira; BRANCO, Paulo Gustavo Gonet. Curso de direito constitucional, 14 ed. rev. e atual. São Paulo: Saraiva Educação, 2019, p. 410.

28 MELO, Lígia Maria Silva de. Segurança jurídica: fundamento do Estado de Direito. Revista de Direito Administrativo \& Constitucional, Belo Horizonte, ano 6, n. 25, p. 133-144, jul./set. 2006, p. 133.

29 BARBOZA, Estefânia Maria de Queiroz. Escrevendo um romance por meio dos precedentes judiciais - uma possibilidade de segurança jurídica para a jurisdição constitucional brasileira. A\&C - Revista de Direito Administrativo \& Constitucional, Belo Horizonte, ano 14, n. 56, p. 177-207, abr./jun. 2014, p. 178.

30 CLÈVE, Clèmerson Merlin; LORENZETTO, Bruno Meneses. Mutação constitucional e segurança jurídica: entre mudança e permanência. Revista de Estudos Constitucionais, Hermenêutica e Teoria do Direito, v. 7, n. 2, p. 136-146, maio-ago. 2015, p. 141.

31 BRASIL. STF, MS 24.268/MG - Minas Gerais, Mandado de Segurança, Relator(a): Min. Ellen Gracie, Relator(a) p/ acórdão: Min. Gilmar Mendes, Julgamento: 05/02/2004, Órgão julgador: Tribunal pleno, Publicação DJ 1709-2004 PP-00053 Ement Vol-02164-01 PP-00154, RDDP n. 23, 2005, p. 133-151, RTJ Vol-00191-03 PP-00922.

32 MARTINS, Eliezer Pereira. Segurança jurídica e certeza do direito em matéria disciplinar - aspectos atuais. Revista de Direito Administrativo, Rio de Janeiro, v. 230, p. 141-152, out./dez. 2002, p. 142.
} 
contra o próprio Estado ${ }^{33}$. Nesse sentido, o Estado deve, não somente tutelar a referida segurança, mas implementar suas funções de forma a promovê-la e não realizar condutas que a neguem.

O Estado de Direito, dentre vários objetivos, visa à estabilidade social e à segurança jurídica e o faz por dois momentos: o legislativo e o decisório, o primeiro com a produção legislativa e o segundo com a produção de decisões. Nesse segundo momento, estuda-se o papel dos julgadores e espera-se que se resolvam os problemas jurídicos de acordo com o direito e não em conformidade com convicções íntimas. Aqui a exigência de justificação é cara sob dois aspectos. O primeiro direciona-se a que as partes tenham seus argumentos e provas produzidas considerados e ponderados. $\mathrm{O}$ segundo é voltado à criação e fomento da confiança de todos nas decisões judiciais. No ponto, credibilidade tem estreita ligação com previsibilidade do atuar judicial ${ }^{34}$.

Daí que se mostra importante dizer que a segurança jurídica tem norte apontado tanto para condutas a serem praticadas pelo Estado, sobretudo aqui para atos judiciais, quanto para situações ocorridas. Assim, deve-se ampliar o estudo do instituto e evitar apenas exemplos ligados ao ato praticado, esquecendo-se a exigência de segurança ao procedimento para a prática do ato. Segue nesses dois caminhos a compreensão de que "nos vínculos entre o Estado e os indivíduos, se assegura uma certa previsibilidade da ação estatal, do mesmo modo que se garante o respeito pelas situações constituídas em consonância com as normas impostas ou reconhecidas pelo poder público", tudo com o fim de "assegurar a estabilidade das relações jurídicas e uma certa coerência na conduta do Estado"35. Apesar de não construído com o problema deste trabalho, Humberto Ávila afirma que a jurisdição tem causado problemas de cognoscibilidade, de confiabilidade e de calculabilidade ${ }^{36}$. Para o presente escrito, importantes são as concepções de confiabilidade e calculabilidade. Aquela pode ser entendida como "a exigência de um ordenamento jurídico protetor de expectativas e garantidor de mudanças estáveis" e esta, como a exigência inerente à segurança jurídica de as pessoas terem a capacidade de prever as consequências jurídicas de atos ou fatos ${ }^{37}$. Nessa ordem de ideias, a conduta do ministro do STF que se louva em dados empíricos cuja

\footnotetext{
33 BARCELLOS, Ana Paula de. Curso de direito constitucional. Rio de Janeiro: Forense, 2018, p. 164.

34 MOREIRA, Egon Bockmann; PEREIRA, Paula Pessoa. Art. 30 da LINDB - O dever público de incrementar a segurança jurídica. Revista de Direito Administrativo, Rio de Janeiro, Edição especial: Direito Público na Lei de Introdução às Normas de Direito Brasileiro - LINDB (Lei no 13.655/2018), p. 243-274, nov. 2018, p. 258-260.

35 SILVA, Almiro do Couto e. O princípio da segurança jurídica (proteção à confiança) no direito público brasileiro e o direito da administração pública de anular seus próprios atos administrativos: o prazo decadencial do art. 54 da lei do processo administrativo da União (Lei n 9.784/99). Revista de Direito Administrativo, Rio de Janeiro, v. 237, p. 271-315, jul./set. 2004, p. 273.

36 ÁVILA, Humberto. Teoria da Segurança Jurídica. 3 ed., revista, atualizada e ampliada. São Paulo: Malheiros Editores, 2016, p. 174.

37 ÁVILA, Humberto. Teoria da Segurança Jurídica. 3 ed., revista, atualizada e ampliada. São Paulo: Malheiros Editores, 2016, p. 138-140.
} 
origem é mencionada, mas dos quais o conhecimento não é franqueado previamente aos demais atores processuais, ou que se apoia em pesquisa da qual não se sabe nem mesmo a fonte, esbarra na configuração acima de segurança jurídica. Isso porque não se espera do julgador que, no momento de julgar, adicione elementos empíricos não estudados anteriormente nos autos do processo, assim como a falta dessa informação prévia às partes sobre a existência de tais dados subtrai das mesmas a capacidade de previsão das consequências jurídicas desse ato judicial.

Também na busca de sedimentar um pensamento que una, de um lado, a previsibilidade e, de outro, a não surpresa, é possível apresentar as dimensões da segurança jurídica. Floriano de Azevedo Marques Neto aborda o tema sob três aspectos: a estabilidade - perenidade aos atos e seus efeitos, ainda quando mudanças ocorrerem; a ponderabilidade - exigindo-se racionalidade e proporcionalidade na aplicação do direito; e previsibilidade - retardando-se grandes alternâncias, armadilhas e surpresas ${ }^{38}$. Outros autores preferem formatar a segurança jurídica em duas dimensões: objetiva e subjetiva. A dimensão objetiva liga-se aos limites da retroatividade dos atos do Estado. A dimensão subjetiva refere-se à proteção e à confiança das pessoas no tocante a atos, procedimentos e condutas estatais ${ }^{39}$. Interessante é o aprofundamento desta última face. A segurança jurídica significa uma tutela contra atos inesperados e prejudiciais do Estado ${ }^{40}$, ou seja, uma nota de bloqueio a mudanças surpreendentes de condutas estatais $^{41}$. Assim, a falta de previsibilidade dificulta a confiança das pessoas no Estado juiz, gerando desincentivos e frustração de expectativas ${ }^{42}$, tudo o que não se deseja para o STF.

Não foi com esse foco que Egon Bockmann Moreira e Paula Pessoa Pereira teceram comentários ao art. 30, da Lei de Introdução às normas do Direito Brasileiro (LINDB). Mas o raciocínio de forma ampla deve ser aqui aplicado. Eles tratam do dever de instauração e autovinculação administrativa a regulamentos, súmulas administrativas

38 NETO, Floriano de Azevedo Marques. Art. 23 da LINDB - O equilíbrio entre mudança e previsibilidade na hermenêutica jurídica. Revista de Direito Administrativo, Rio de Janeiro, Edição especial: Direito Público na Lei de Introdução às Normas de Direito Brasileiro - LINDB (Lei no 13.655/2018), p. 93-112, nov. 2018, p. 99.

39 MOREIRA, Egon Bockmann; PEREIRA, Paula Pessoa. Art. 30 da LINDB - O dever público de incrementar a segurança jurídica. Revista de Direito Administrativo, Rio de Janeiro, Edição especial: Direito Público na Lei de Introdução às Normas de Direito Brasileiro - LINDB (Lei no 13.655/2018), p. 243-274, nov. 2018, p. 255.

40 CLÈVE, Clèmerson Merlin; LORENZETTO, Bruno Meneses. Mutação constitucional e segurança jurídica: entre mudança e permanência. Revista de Estudos Constitucionais, Hermenêutica e Teoria do Direito, v. 7, n. 2, p. 136-146, maio-ago. 2015, p. 142-144.

41 SILVA, Almiro do Couto e. O princípio da segurança jurídica (proteção à confiança) no direito público brasileiro e o direito da administração pública de anular seus próprios atos administrativos: o prazo decadencial do art. 54 da lei do processo administrativo da União (Lei n 9.784/99). Revista de Direito Administrativo, Rio de Janeiro, v. 237, p. 271-315, jul./set. 2004, p. 275.

42 MOREIRA, Egon Bockmann; PEREIRA, Paula Pessoa. Art. 30 da LINDB - O dever público de incrementar a segurança jurídica. Revista de Direito Administrativo, Rio de Janeiro, Edição especial: Direito Público na Lei de Introdução às Normas de Direito Brasileiro - LINDB (Lei no 13.655/2018), p. 243-274, nov. 2018, p. 254. 
e respostas a consultas e trazem dois desdobramentos: a institucionalização do efetivo respeito e a estabilização institucional das decisões. Trabalhando este segundo aspecto, vinculam tal ideia à aceitabilidade e o efetivo cumprimento das decisões à reputação institucional, para este escrito, do STF. E daí, afirmam que "a estabilidade da legitimidade institucional e decisória é que garante esta reputação e, por conseguinte, a aceitabilidade das decisões" e, por isso, "[a] percepção de alguma atuação ilegítima, fora dos argumentos jurídicos estabilizados, traz grande insegurança e déficit de confiança por parte dos atores políticos, sociais e cidadãos"43. A introdução de dado empírico, sem prévia ciência dos atores processuais, por parte de ministro do STF, que o utiliza de imediato em sua decisão ou voto, traz elemento novo, não necessariamente indene de crítica. Ele não é um argumento jurídico estabilizado. Pelo contrário, é um fundamento que surpreende a todos, inclusive os demais ministros da Corte.

Em um jogo de sentidos que se misturam, segurança ocasiona previsibilidade que importa em confiança. Porém, o contrário também é verdadeiro. A insegurança dá espaço à imprevisibilidade e esta leva à desconfiança. $O$ interessante é que segurança e previsibilidade - o que inclui seus antônimos - podem ser causa e efeito uma da outra. E o resultado dessa conta é a confiança.

Uma conduta judicial que aporta para dentro da decisão a ser proferida elementos não presentes nos autos pode ser qualificada como imprevisível pela parte. Se esta trabalha com o que conhece existente no processo. Se isso traz certo resguardo igualmente à outra parte. Parece correto dizer que o magistrado que introduz elemento novo e, portanto, desconhecido dos demais atores processuais, age de forma imprevisível. Se, além disso, magistrados de órgão colegiado, como ficou demonstrado acima, utilizam-se de dados empíricos e chegam a soluções opostas, a segurança jurídica resta ainda mais comprometida. A desconfiança, não por responsabilidade das partes ou da própria sociedade, será o tom presente. É realmente difícil justificar fundamentadamente como dados empíricos podem direcionar votos em sentidos diversos.

Isso leva à necessidade de antes de autorizar-se o uso de investigações empíricas pelo julgador, as mesmas serem estudadas pelos envolvidos no processo. Tal passo prévio espantará a surpresa e tornará mais previsível o norte do julgamento. Caso os estudos tenham sentidos contrários, é o momento inclusive de falsear um ou outro. De todo modo, de insegurança jurídica não se poderá mais falar. Assim, para a sociedade como um todo e para as partes e envolvidos, em particular, pairará um sentimento de confiança no sentido de que, caso elementos empíricos surjam no conhecimento do magistrado, este antes levará os mesmos à ciência dos demais.

\footnotetext{
43 MOREIRA, Egon Bockmann; PEREIRA, Paula Pessoa. Art. 30 da LINDB - O dever público de incrementar a segurança jurídica. Revista de Direito Administrativo, Rio de Janeiro, Edição especial: Direito Público na Lei de Introdução às Normas de Direito Brasileiro - LINDB (Lei n 13.655/2018), p. 243-274, nov. 2018, p. 247.
} 
A presente subseção, assim, buscou extrair da segurança jurídica o valor fundamental de não surpresa. O mesmo empreendimento será realizado abaixo, entretanto com relação ao contraditório.

\subsection{A extração constitucional do contraditório}

Para efeito de concretizar um valor constitucional da não surpresa é possível utilizar um modelo constitucional de processo, pelo qual se faz uma releitura dos institutos do processo com olhos voltados para o Estado Democrático de Direito. Através de uma crítica à escassez de diálogo processual, às decisões tomadas solitariamente pelo juiz e ao esquecimento da efetividade normativa e sua garantia de eficiência e legitimidade, com respectiva possibilidade de influência de todos os sujeitos processuais, foca-se o processo como estrutura dialógica de formação de provimentos e garantia de direitos fundamentais. Para tanto, deve-se ter uma percepção dinâmica dos princípios constitucionais e, ao mesmo tempo, promover a superação de dois modelos de processo, que hoje já não se encaixam. O processo como instituição estatal de bem estar social, pelo qual o juiz, formalmente, é o diretor do processo; e, materialmente, tem controle e iniciativa oficiosa na colheita da prova, deposita uma esperança acrítica e desmedida no magistrado. E, por sua vez, o processo como relação jurídica, categoriza o juiz como ator superior, subordinando, indevidamente, as partes ao magistrado. Daí que um juiz solucionista, caracterizado como sabedor do que é o bem comum, e solipsista, qualificado como tomador isolado de decisões, afasta a teoria da realidade constitucional exigível e permite o alijamento das partes do discurso processual ${ }^{44}$. Por conta da democratização processual, é visível um dissenso do que é o bem comum e imperfeita a imagem de um juiz solitário com ideias privilegiadas de justiça ${ }^{45}$.

Nesse sentido, a doutrina processualista vem reclamando um espaço discursivo aberto pelo processo, para problematização e formação de decisão. Uma forma para se alcançar esse desiderato é trabalhar a concepção de contraditório. Essencial para a ideia de processo, o contraditório durante longo tempo foi visto como um princípio que obedecia ao comando de informação e reação. Assim, à parte deveria ser entregue determinada informação e facultada a respectiva reação ${ }^{46}$. Com o tempo, essa formatação vem sofrendo uma releitura e hoje fala-se em o contraditório guardar em si uma

44 THEODORO JÚNIOR, Humberto; NUNES, Dierle José Coelho. Uma dimensão que urge reconhecer ao contraditório no direito brasileiro: sua aplicação como garantia de influência, de não surpresa e de aproveitamento da atividade processual. Revista de Processo, vol. 168, p. 107-141, fev. 2009, DTR\2009\156.

45 NUNES, Dierle José Coelho. Teoria do processo contemporâneo: por um processualismo constitucional democrático. Revista da Faculdade de Direito do Sul de Minas, p. 13-29, Edição Especial - 2018, p. 13-25.

46 LUCON, Paulo Henrique dos Santos. Tutela do contraditório no novo código de processo civil: vedação à decisão-surpresa; requisito para extensão dos limites objetivos da coisa julgada; identificação das decisões imotivadas. Revista Eletrônica de Direito Processual, Rio de Janeiro, Ano 10, v. 17, n. 1, p. 164-192, jan. a jun. 2016, p. 166. 
tríplice lógica. Funcionaria o referido princípio a noção de informação, reação e consideração. Abandonando-se a mera bilateralidade da audiência, passa-se à necessária consideração, na qual a decisão judicial deve enfrentar os argumentos apresentados pelas partes nas respectivas reações ${ }^{47}$.

Tal pensamento traz à tona a distinção entre contraditório estático e contraditório dinâmico. O contraditório estático seria, pois, a simples oitiva das partes, na sequência evolutiva dos atos processuais, sendo o juiz um mero espectador do litígio ${ }^{48}$. Entretanto, o contraditório dinâmico admite outra estruturação. Por ele, há a possibilidade de influência sobre o progresso do processo e em relação à configuração da decisão ${ }^{49}$. No ponto, deseja-se a efetivação de um contraditório material ou substancial, em que as considerações sejam realmente levadas em conta, com potencialidade de influenciar no resultado final, não se atribuindo peso ao simples ato anterior, mas sim à sua utilidade $^{50}$. Há aí uma comparticipação pela qual os atores do processo podem influenciar na formação das decisões, com real discussão afiançada pelo fomento ao debate e sem o protagonismo isolado de um ou outro sujeito processual. Partes e magistrado atuam efetivamente em uma comunidade de trabalho ${ }^{51}$.

Toda essa exposição leva à possibilidade de serem fixados, através do princípio do contraditório, duas garantias e alguns deveres. Em primeiro lugar, pode ser dito que o contraditório assegura uma oportunidade de participação ${ }^{52}$, mas com real chance de contribuição da parte ${ }^{53}$. Exige ele um efetivo diálogo ${ }^{54}$. Funciona, então, como uma garantia de influência ${ }^{55}$ especialmente em relação ao magistrado. Dessa forma, passa-se

47 DE OLIVEIRA JUNIOR, Zulmar Duarte. Devido processo legal: contraditório (trinômio informação, reação e consideração) e o novo CPC. Revista Eletrônica de Direito Processual, Rio de Janeiro, Ano 5, v. 7, n. 7, p. 205220, jan. a jun. 2011, p. 213-214.

48 THEODORO JÚNIOR, Humberto. Processo justo e contraditório dinâmico. Revista de Estudos Constitucionais, Hermenêutica e Teoria do Direito, v. 2, n. 1, p. 64-71, jan. a jun. 2010, p. 69.

49 THEODORO JÚNIOR, Humberto; NUNES, Dierle José Coelho. Uma dimensão que urge reconhecer ao contraditório no direito brasileiro: sua aplicação como garantia de influência, de não surpresa e de aproveitamento da atividade processual. Revista de Processo, vol. 168, p. 107-141, fev. 2009, DTR\2009\156.

50 DE OLIVEIRA JUNIOR, Zulmar Duarte. Devido processo legal: contraditório (trinômio informação, reação e consideração) e o novo CPC. Revista Eletrônica de Direito Processual, Rio de Janeiro, Ano 5, v. 7, n. 7, p. 205220, jan. a jun. 2011, p. 214.

51 DOS SANTOS, Welder Queiroz. A vedação à prolação de "decisão surpresa" na Alemanha. Revista de Processo, vol. 240, p. 425-435, fev. 2015, DTR\2015\817.

52 LUCON, Paulo Henrique dos Santos. Tutela do contraditório no novo código de processo civil: vedação à decisão-surpresa; requisito para extensão dos limites objetivos da coisa julgada; identificação das decisões imotivadas. Revista Eletrônica de Direito Processual, Rio de Janeiro, Ano 10, v. 17, n. 1, p. 164-192, jan. a jun. 2016, p. 167.

53 MOREIRA, José Carlos Barbosa. Breve notícia sobre a reforma do processo civil alemão. In: Temas de Direito Processual, Oitava Série, Rio de Janeiro: Saraiva, p. 199-210, 2004, p. 201.

54 THEODORO JÚNIOR, Humberto. Processo justo e contraditório dinâmico. Revista de Estudos Constitucionais, Hermenêutica e Teoria do Direito, v. 2, n. 1, p. 64-71, jan. a jun. 2010, p. 69.

55 NUNES, Dierle José Coelho. Teoria do processo contemporâneo: por um processualismo constitucional democrático. Revista da Faculdade de Direito do Sul de Minas, p. 13-29, Edição Especial - 2018, p. 13-25. 
a impedir a existência da figura do juiz isolado que toma decisões sozinho, um juiz solipsista ${ }^{56}$.

Para o presente trabalho, essa face do contraditório é relevante, porque, como visto, os ministros do STF têm se utilizado de dados para proferir votos ou decisões monocráticas seguindo uma lógica pragmática. Observa-se, por um lado, que as pesquisas, levadas a efeito pelo próprio julgador, muitas vezes não são entranhadas aos autos, apesar de referenciadas. Em outras oportunidades, os ministros tão somente mencionam o acesso às mesmas, sem ser possível mesmo saber quais são e se concretamente são investigações empíricas. A visão acima de contraditório garantia, portanto, exige no ponto uma participação efetiva e dialógica sobre tais dados.

Surge, entretanto, a questão sobre o maior poder instrutório do juiz, com o abandono da passividade judicial na busca da tutela do direito material, quando enxergada uma desigualdade no curso do processo, e da vulnerabilidade processual da parte, que faz dela vítima de suas dificuldades e importa em descumprimento do seu ônus probatório ${ }^{57}$. Porém, a atuação de ofício do juiz ainda assim não torna prescindível o respeito ao contraditório ${ }^{58}$. Daí se coloca a segunda garantia. O magistrado, ao aplicar essa formatação do contraditório, deverá ser mais aberto a uma construção plural da decisão e as partes serão sempre ouvidas sobre os temas que ele tem em vista, impedindo-se que os sujeitos processuais sejam surpreendidos. Esta é a garantia contra decisões surpresa.

Como já disse Barbosa Moreira, em estudo voltado para o direito alemão, "em princípio é vedado ao tribunal colocar-se, para fundamentar sua decisão, em ponto de vista estranho ao das partes", exceto se "Ihes faça a respectiva indicação e lhes dê ensejo de manifestar-se" ${ }^{\prime \prime 2}$. Assim, como pronunciamento judicial apoiado em fundamentos não previamente debatido pelas partes ${ }^{60}$, a decisão surpresa é vetada pelo contraditório. E então é bastante pertinente a exigência de o magistrado "ainda que possa e deva agir de ofício na produção de provas, facultando-se-lhe, portanto, extrair da rede mundial de computadores alguma informação para subsidiar o julgamento, convidar

\footnotetext{
56 CÂMARA, Alexandre Antônio Franco Freitas. Dimensão processual do princípio do devido processo constitucional. Revista de Estudos e Debates - CEDES, v. 2, n. 2, p. 55-68, jan.-jun. 2017, p. 64.

57 DE CARVALHO, Sabrina Nasser. Premissas para a melhor compreensão da dinamização do ônus da prova no novo CPC. Revista Eletrônica de Direito Processual, Rio de Janeiro, Ano 11, v. 18, n. 1, p. 346-376, jan. a abr. 2017, p. 356-358 e 361-362.

58 MALLET, Estêvão. Notas sobre o problema da chamada "decisão-surpresa". Revista da Faculdade de Direito, Universidade de São Paulo, v. 109, p. 389-414, jan./dez. 2014, p. 396-397.

59 MOREIRA, José Carlos Barbosa. Breve notícia sobre a reforma do processo civil alemão. In: Temas de Direito Processual, Oitava Série, Rio de Janeiro: Saraiva, p. 199-210, 2004, p. 202.

60 CÂMARA, Alexandre Antônio Franco Freitas. Dimensão processual do princípio do devido processo constitucional. Revista de Estudos e Debates - CEDES, v. 2, n. 2, p. 55-68, jan.-jun. 2017, p. 65.
} 
as partes a falar sobre o material produzido, antes de utilizá-lo ao sentenciar" ${ }^{\prime \prime 1}$. Deste modo, os ministros do STF não estão proibidos de fazerem uso do pragmatismo. Porém, os dados e pesquisas empíricas precisam, antes de compor um voto ou uma decisão monocrática, ser estudadas pelas partes processuais ou pela parcela da sociedade cujos interesses serão afetados pela decisão da Corte.

Se sob um ângulo, trata-se o tema pelo aspecto da garantia, sob outro, ele é abordado através da concepção de dever. Então, o contraditório importa em garantia de influência e em garantia de não surpresa, sobretudo com uma conotação protetiva às partes e aos evolvidos do processo. Mas também significa, como que em um outro lado da moeda, um dever ao magistrado. Nessa lógica, o julgador deve sempre consultar as partes sobre assuntos não discutidos. Com isso, provoca-se o debate e fomenta-se o diálogo. Dessa forma, impõe-se ao juiz o dever de informar o que pretende fazer e o rumo que deseja tomar' ${ }^{62}$. É um verdadeiro dever de advertência, pelo qual o magistrado comunica aos sujeitos do processo sobre temas não debatidos e que podem ser objeto de decisão ${ }^{63}$. E mais, se a arquitetura do princípio do contraditório é essa, o mesmo deve ser concretizado em todos os momentos processuais ${ }^{64} \mathrm{e}$, em paralelo, a garantia de não surpresa, igualmente, deve ser observada em todos os graus de jurisdição ${ }^{65}$. Com essa lógica, percebe-se haver um dever sobre os ministros do STF de, caso desejem utilizar-se de investigações empíricas, fomentar uma discussão prévia sobre as mesmas pelas partes e envolvidos no respectivo processo.

Assim, é possível se chegar a mais uma conclusão provisória. Pelo que foi exposto nesta subseção, do contraditório se extrai o valor fundamental de não surpresa. Do mesmo modo, da subseção anterior é possível compreender da segurança jurídica o valor de não surpresa. Com isso tudo, portanto, demonstrou-se porque os ministros do STF não devem usar de dados empíricos sem o prévio conhecimento dos afetados pela futura decisão. Ultrapassado esse momento, o trabalho passará a apresentar proposições de como o Tribunal pode executar tal tarefa.

61 MALLET, Estêvão. Notas sobre o problema da chamada "decisão-surpresa". Revista da Faculdade de Direito, Universidade de São Paulo, v. 109, p. 389-414, jan./dez. 2014, p. 404.

62 THEODORO JÚNIOR, Humberto. Processo justo e contraditório dinâmico. Revista de Estudos Constitucionais, Hermenêutica e Teoria do Direito, v. 2, n. 1, p. 64-71, jan. a jun. 2010, p. 70.

63 DOS SANTOS, Welder Queiroz. A vedação à prolação de "decisão surpresa" na Alemanha. Revista de Processo, vol. 240, p. 425-435, fev. 2015, DTR\2015\817.

64 DE OLIVEIRA JUNIOR, Zulmar Duarte. Devido processo legal: contraditório (trinômio informação, reação e consideração) e o novo CPC. Revista Eletrônica de Direito Processual, Rio de Janeiro, Ano 5, v. 7, n. 7, p. 205 220, jan. a jun. 2011, p. 215.

65 LUCON, Paulo Henrique dos Santos. Tutela do contraditório no novo código de processo civil: vedação à decisão-surpresa; requisito para extensão dos limites objetivos da coisa julgada; identificação das decisões imotivadas. Revista Eletrônica de Direito Processual, Rio de Janeiro, Ano 10, v. 17, n. 1, p. 164-192, jan. a jun. 2016, p. 172. 


\section{PROPOSIÇÕES}

Na seção que se inaugura o trabalho apresentará algumas proposições para a questão detectada. Foi visto que o STF tem proferido decisões utilizando-se do pragmatismo, dizendo-se ou deixando que o qualifiquem como uma Corte consequencialista. Todavia, críticas vêm sendo direcionadas ao Tribunal devido à sua pouca preocupação em como realizar essa tarefa, aproximando-se seu atuar muito mais de um consequenciachismo.

\subsection{A não surpresa como testagem do consequencialismo e contra o consequenciachismo}

Ficou demonstrado que a não surpresa tem um valor fundamental. A formatação da segurança jurídica e o esquema do contraditório evidenciam isso. E com base no desenho acima feito desses princípios que, na preocupação do presente trabalho, desaguam na não surpresa, é possível testar se o Tribunal, em um caso concreto, está sendo consequencialista ou consequenciachista. Explica-se. Com a impossibilidade de o magistrado simplesmente inserir em seus votos ou decisões monocráticas investigações empíricas, com as características já ressaltadas linhas acima, para imediatamente implementar o julgamento, sem que os atores processuais se debrucem sobre tais dados, prestigia-se a não surpresa.

Essa estrutura, além de homenagear a segurança jurídica e o contraditório, ainda permite separar qual o magistrado, em determinado caso, fez adequado uso do consequencialismo. Ademais, impede que os próprios pares sigam o raciocínio levado a efeito no voto de forma acrítica, já que terão mais tempo para checar se as pesquisas usadas qualificam-se como adequadas ao caso em análise.

Com isso tudo em mente, chegou o momento de abaixo traçar alguns parâmetros para o uso de estudos, dados e pesquisas por parte do STF. Essa configuração deve ser pensada de forma a não importar em antecipação de voto, por parte do magistrado que faz uso do caráter empírico, e também de modo a não auxiliar a parte inerte ou omissa que não se desincumbiu em bem executar seu ônus probatório.

\subsection{O processo subjetivo}

São inúmeros os processos subjetivos submetidos às competênciais originárias e recursais do STF. Qualifica-se como processo subjetivo aquele que tem partes, lide e resistência à pretensão ${ }^{66}$. Nele os princípios constitucionais processuais, como, por exemplo, o contraditório, o devido processo legal e a ampla defesa têm plena aplicação.

66 ABBOUD, Georges. Processo constitucional brasileiro. 2 ed. rev., atual. e ampl. São Paulo: Thomson Reuters Brasil, Revista dos Tribunais, 2018, p. 877-880. 
Na hipótese as partes afetadas pela introdução, por ministro da Corte, no momento do julgamento, de dado empírico novo, podem ser identificadas. Por exemplo, no caso do recurso extraordinário, podem ser apontados o recorrente e o recorrido. No caso de habeas corpus, o impetrante e o paciente podem ser afetados, se o estudo empírico lhes for prejudicial. Em sendo favorável, porque atua na condição de custos iuris ${ }^{67}$, é possível indicar a Procuradoria-Geral da República como ator processual interessado a manifestar-se quanto à nova investigação.

Não obstante, uma distinção precisa ser feita. Diferente do habeas corpus e de outras demandas guiadas pela ideia de competência originária, o recurso extraordinário ascende tema já debatido em outras instâncias julgadoras. Nasce aí um problema de os ministros do STF inserirem pesquisas novas em seus votos e decisões monocráticas: o fenômeno da preclusão e a questão do ônus da prova. Tal dificuldade possui um grau menor nas demandas de competência originária, em que pese a existência de algumas exigirem prova pré constituída. Por causa desse contorno, em processo subjetivo, o ministro do STF deve agir com mais parcimônia e cautela, para que sua inserção de estudo empírico não signifique a violação da formatação própria de alguns tipos de demanda constitucional. Nesse sentido, o dado empírico pode servir de auxílio à decisão ou voto, mas não pode, em regra, importar em elemento probatório dos fatos constitutivos do direito alegado.

Importante para tanto é o fenômeno da preclusão. A preclusão tem raiz na segurança jurídica, trazendo ordem ao processo, por afiançar neste um caráter evolutivo e dinâmico. Neste sentido, Marinoni e Mitidiero explicam que "ao precluir a prática de determinado ato ou ao se encerrar o debate a respeito de determinada questão, torna-se certa e estável dentro do processo a situação jurídica consolidada", o que gera "expectativa legítima às partes no não retrocesso do procedimento e direito à observância do resultado da preclusão". Ainda sobre isso, os autores afirmam que processo seguro é aquele "em que as regras de preclusão são devidamente (...) observadas pelo juiz na condução do processo" ${ }^{\prime \prime}$.

Com olhos nessa preocupação e considerando que o dado, aqui discutido, não está nos autos e vendo o ministro que eventualmente poderá fazer uso do mesmo, um parâmetro importante seria abrir espaço às partes para que se expressem sobre o conteúdo do mesmo, podendo, inclusive, apresentar estudo científico em sentido diverso. Sob pena de violação da cognição levada a efeito nas instâncias passadas e por causa da preclusão que atingiu as partes, não seria possível efetivamente produzir provas

67 BRASIL. STF, RHC 84.404/SP - São Paulo; Recurso em Habeas Corpus; Relator: Min. Carlos Britto; Julgamento: 29/03/2005; Órgão julgador: Primeira Turma; Publicação DJ 16-12-2005 PP-00084 Ement Vol-02218-03 PP00507 LexSTF v. 28, n. 326, 2006, p. 391-413.

68 SARLET, Ingo; MARINONI, Luiz Guilherme; MITIDIERO, Daniel. Curso de direito constitucional. 4 ed. ampl., incluindo novo capítulo sobre princípios fundamentais. São Paulo: Saraiva, 2015, p. 784-785. 
sobre os fatos constitutivos do direito nesse momento. $\mathrm{O}$ caso seria apenas de contraditar um estudo do qual o ministro, sem sinalizar sua intenção de voto, achou pertinente ao caso. A atenção se voltaria a não inovar no arcabouço probatório já produzido.

Além disso, parece relevante pontuar, ainda que de forma inicial, as características do estudo cuja utilização é autorizada ao ministro do STF. Deve o mesmo ser de acesso, ao menos, a uma comunidade científica ou estar facilmente disponível a quem interesse (por exemplo, na Internet). Com a preocupação de acesso ao dado busca-se, por um lado, a maior facilidade de contato com o conhecimento e, por outro, a maior possibilidade de debate desse conhecimento.

Com esses traços deseja-se, ao máximo, promover o uso adequado do consequencialismo. As considerações desta subseção, somadas às da próxima são relevantes para se evitar a surpresa em processos subjetivos. Assim, quando admitida a inserção de estudo empírico nos moldes aqui expostos, deve o magistrado abrir às partes a possibilidade de manifestação, em prestígio aos princípios constitucionais da segurança jurídica e do contraditório.

\subsection{O processo objetivo}

O processo objetivo caracteriza-se por solucionar uma questão constitucional, sem o objetivo de dirimir uma lide, não existindo pretensão resistida. Já foi dito que os legitimados ativos não buscam a tutela de um direito subjetivo, mas a defesa da ordem constitucional objetiva, não havendo que se falar, propriamente, em partes. Por isso, tem-se uma fiscalização abstrata da constitucionalidade de normas infraconstitucionais.

A legislação positivada em relação ao assunto, sobretudo a Lei no 9.868, de 10 de novembro de 1999, e a Lei no 9.882, de 03 de dezembro de 1999, sinalizam situação não muito próxima a que está sendo aqui analisada. É a hipótese de o relator entender pela necessidade de novos esclarecimentos sobre alguma circunstância e determinar nos autos a produção desse novo elemento que, portanto, estará no processo, com acesso, no mínimo, aos que nele podem atuar ${ }^{69}$. O reconhecimento da relevância da aferição de elementos fáticos, notadamente para a definição do sopesamento entre princípios constitucionais em colisão, consiste em relevante inovação legislativa. Tais informações, somadas à manifestação de experts, terão enorme valia para a solução de questões constitucionais complexas.

Nada obstante isso, o ponto central desse escrito é diverso. Como demonstrado em subseção anterior, o que se busca alterar é um padrão de atuação judicial consistente em inserir dados empíricos em decisões judiciais sem prévia oitiva das partes

69 Em ADI, rege a matéria o art. 9, da Lei n॰ 9.868/99. Na ação declaratória de constitucionalidade, o assunto está no art. 20, da mesma lei, que possui igual redação. E na arguição de descumprimento de preceito fundamental, os arts. $6^{\circ}$ e $7^{\circ}$, da Lei no 9.882/99 tratam de modo semelhante o tema. 
interessadas, principalmente quando tais informações eram até então estranhas aos autos do processo. E mais, em algumas vezes não é o relator que lança mão dessas investigações, sendo ainda mais ofensivo à segurança jurídica e ao contraditório que os últimos magistrados a votarem em órgão colegiado se utilizem desse método decisório, surpreendendo até mesmo seus colegas.

Embora os processos objetivos de competência originária do STF não apresentem as mencionadas dificuldades relativas aos processos subjetivos de competência recursal do STF (sobretudo quanto ao momento adequado de produção de provas dos fatos constitutivos do direito alegado), existem duas ordens de preocupação - que como dito também se aplicam à subseção anterior. Como a inserção do dado empírico afeta, de alguma forma, os interesses concretamente em jogo no julgamento - ainda que se insista em dizer haver apenas o interesse de tutela da ordem jurídica constitucional -, deve ser aberta oportunidade aos legitimados ativos e passivos, aos amici curiae e aos demais atores do processo (por exemplo, Procurador-Geral da República e Advogado-Geral da União) de se manifestarem especificamente sobre tal estudo, possibilitando-se inclusive o ingresso de novos amici curiae. Portanto, propõe-se que o julgador, mesmo sem adiantar seu entendimento, aponte antecipadamente a existência de dado empírico relevante. Dessa forma, a indicação antecipada da existência da investigação aliada ao oferecimento de espaço para que se entregue eventual pesquisa científica oposta à que o julgador tem em mãos visa adequar o uso do consequencialismo aos princípios constitucionais da segurança jurídica e do contraditório ${ }^{70}$.

Uma segunda preocupação sinalizada linhas acima se dá quando o julgamento já está avançado entre os ministros e um utiliza-se em sua fundamentação de dados empíricos antes inexistentes nos autos. Como deixado claro nesse trabalho, esse atuar surpreende os envolvidos no processo e inclusive os seus pares. Assim, sugere-se que os mesmos passos descritos no parágrafo anterior sejam percorridos, porém com um detalhe. Deve o magistrado, caso já tenha em mãos a pesquisa antes do início da exposição dos votos, indicar a existência dessa investigação, para então percorrer o caminho logo acima descrito. Caso a pesquisa, entretanto, tenha chegado ao mesmo no transcorrer das declarações de voto, para que não haja surpresa, o julgamento terá que retornar ao ponto de dar publicidade da mesma nos autos e chamar eventuais interessados a se manifestarem.

\footnotetext{
70 A possibilidade de admissão de amicus curiae fora do prazo das informações não parece ser um problema. Ademais, mesmo não tendo em mente o assunto trabalho aqui, há doutrina crítica a decisões intuitivas do STF. $\mathrm{E}$, referindo-se à análise de fatos, defensiva do "desenvolvimento de técnicas que possibilitem decisões racionalmente fundadas por parte do órgão judicial de controle". MARTINS, Ives Gandra da Silva; MENDES, Gilmar Ferreira. Controle concentrado de constitucionalidade: comentários à Lei n. 9.868, de 10-11-1999. 2 ed. São Paulo: Saraiva, 2005, p. 252 e 283.
} 


\section{CONSIDERAÇÕES FINAIS}

O presente trabalho buscou demonstrar que o padrão de emprego de dados empíricos pelo STF pode ser aprimorado com vistas a mais efetiva proteção dos princípios constitucionais da segurança jurídica e do contraditório. Esta proposta se torna, a nosso ver, mais relevante a partir do momento em que se constata crescente uso de dados empíricos pelos ministros do STF como fundamentos das suas decisões e votos. Essa postura tende a gerar surpresa aos atores do processo e aos demais ministros, tornando a deliberação mais pobre e não resguardando de maneira eficaz a segurança jurídica e o contraditório. Frente a esse cenário, debruçou-se a primeira seção em organizar as ideias sobre consequencialismo e consequenciachismo, com a finalidade de definir parâmetros para esclarecer o adequado uso do primeiro. Assim, foram estudados o pragmatismo e, especialmente, o consequencialismo e o empirismo, assim como se delimitou o entendimento do que significa o consequenciachismo. Daí, foram apresentados três julgamentos importantes do STF, nos quais demonstrou-se a necessidade de aprimoramento do uso de dadas empíricos pela Corte.

Depois disso, ante o problema acima constatado, foi identificado um valor fundamental da não surpresa. Para chegar ao mesmo, desenvolveram-se as ideias de segurança jurídica e de contraditório. Assentada que a não surpresa tem raiz constitucional, partiu-se para a construção de parâmetros de como testar o consequencialismo e de como impedir o consequenciachismo.

Nesse sentido, a terceira seção procurou entregar argumentos que visam aferir se o consequencialismo está sendo realizado com algum método pelo STF. Dividindo em subseções para tratar separadamente dos processos objetivos e subjetivos, a cautela foi propor parâmetros nos quais não haja surpresa às partes ou envolvidos no processo e nem aos demais ministros do Tribunal. Somou-se a isso o cuidado com o fenômeno da preclusão e com o instituto do ônus da prova.

\section{REFERÊNCIAS}

ABBOUD, Georges. Processo constitucional brasileiro. 2 ed. rev., atual. e ampl. São Paulo: Thomson Reuters Brasil, Revista dos Tribunais, 2018.

ARGUELHES, Diego Werneck; LEAL, Fernando. Pragmatismo como [Meta] Teoria da Decisão Judicial: Caracterização, Estratégias e Implicações. In: SARMENTO, Daniel (coord.). Filosofia e Teoria Constitucional Contemporânea. Rio de Janeiro: Lumen Juris, 2009.

ÁVILA, Humberto. Teoria da Segurança Jurídica. 3 ed., revista, atualizada e ampliada. São Paulo: Malheiros Editores, 2016.

BARBOZA, Estefânia Maria de Queiroz. Escrevendo um romance por meio dos precedentes judiciais - uma possibilidade de segurança jurídica para a jurisdição constitucional brasileira. A\&C - Revista de Direito Administrativo \& Constitucional, Belo Horizonte, ano 14, n. 56, p. 177-207, abr./jun. 2014. 
BARCELLOS, Ana Paula de. Curso de direito constitucional. Rio de Janeiro: Forense, 2018.

BRASIL. STF, ADI 5.874 MC/DF - Distrito Federal; Medida Cautelar na Ação Direta de Inconstitucionalidade; Relator: Min. Roberto Barroso; Julgamento: 12/03/2018; Publicação Processo Eletrônico DJE-049 Divulg 13/03/2018 Public 14/03/2018.

BRASIL. STF, HC 126.292/SP - São Paulo; Habeas Corpus; Relator: Min. Teori Zavascki; Julgamento: 17/02/2016; Órgão julgador: Tribunal Pleno; Publicação Processo Eletrônico DJe-100 Divulg 1605-2016 Public 17-05-2016.

BRASIL. STF, MS 24.268/MG - Minas Gerais, Mandado de Segurança, Relator(a): Min. Ellen Gracie, Relator(a) p/ acórdão: Min. Gilmar Mendes, Julgamento: 05/02/2004, Órgão julgador: Tribunal pleno, Publicação DJ 17-09-2004 PP-00053 Ement Vol-02164-01 PP-00154, RDDP n. 23, 2005, p. 133-151, RTJ Vol-00191-03 PP-00922.

BRASIL. STF, RE 888.815/RS - Rio Grande do Sul; Recurso Extraordinário; Relator: Min. Roberto Barroso; Relator p/ Acórdão: Min. Alexandre de Moraes; Julgamento: 12/09/2018; Órgão julgador: Tribunal Pleno; Publicação Processo Eletrônico DJE-055 Divulg 20-03-2019 Public 21-03-2019.

BRASIL. STF, RHC 84.404/SP - São Paulo; Recurso em Habeas Corpus; Relator: Min. Carlos Britto; Julgamento: 29/03/2005; Órgão julgador: Primeira Turma; Publicação DJ 16-12-2005 PP-00084 Ement Vol-02218-03 PP-00507 LexSTF v. 28, n. 326, 2006, p. 391-413.

CÂMARA, Alexandre Antônio Franco Freitas. Dimensão processual do princípio do devido processo constitucional. Revista de Estudos e Debates - CEDES, v. 2, n. 2, p. 55-68, jan.-jun. 2017.

CLÈVE, Clèmerson Merlin; LORENZETTO, Bruno Meneses. Mutação constitucional e segurança jurídica: entre mudança e permanência. Revista de Estudos Constitucionais, Hermenêutica e Teoria do Direito, v. 7, n. 2, p. 136-146, maio-ago. 2015.

DE CARVALHO, Sabrina Nasser. Premissas para a melhor compreensão da dinamização do ônus da prova no novo CPC. Revista Eletrônica de Direito Processual, Rio de Janeiro, Ano 11, v. 18, n. 1, p. 346-376, jan. a abr. 2017.

DE MENDONÇA, José Vicente Santos. Art. 21 da LINDB - Indicando consequências e regularizando atos e negócios. Revista de Direito Administrativo, Rio de Janeiro, Edição especial: Direito Público na Lei de Introdução às Normas de Direito Brasileiro - LINDB (Lei nº 13.655/2018), p. 43-61, nov. 2018.

DE MENDONÇA, José Vicente Santos. Em defesa do consequenciachismo. Direito do Estado, ano 2018, 16 set. 2018, n 413. Disponível em: <http://www.direitodoestado.com.br/colunistas/jose-vicente-santos-mendonca/em-defesa-do-consequenciachismo>. Acesso em: 21 jul. 2019.

DE OLIVEIRA JUNIOR, Zulmar Duarte. Devido processo legal: contraditório (trinômio informação, reação e consideração) e o novo CPC. Revista Eletrônica de Direito Processual, Rio de Janeiro, Ano 5, v. 7, n. 7, p. 205-220, jan. a jun. 2011. 
DOS SANTOS, Welder Queiroz. A vedação à prolação de "decisão surpresa" na Alemanha. Revista de Processo, vol. 240, p. 425-435, fev. 2015, DTR\2015\817.

DWORKIN, Ronald. 0 direito da liberdade: a leitura moral da Constituição norte-americana. Tradução Marcelo Brandão Cipolla; revisão técnica Alberto Alonso Muñoz. São Paulo: Martins Fontes, 2006.

LEAL, Fernando. Consequenciachismo, principialismo e deferência: limpando o terreno. Jota, 01 out. 2018. Disponível em: <https://www.jota.info/paywall?redirect_to=//www.jota.info/stf/supra/consequenciachismo-principialismo-e-deferencia-limpando-o-terreno-01102018>. Acesso em: 21 jul. 2019.

LUCON, Paulo Henrique dos Santos. Tutela do contraditório no novo código de processo civil: vedação à decisão-surpresa; requisito para extensão dos limites objetivos da coisa julgada; identificação das decisões imotivadas. Revista Eletrônica de Direito Processual, Rio de Janeiro, Ano 10, v. 17, n. 1, p. 164-192, jan. a jun. 2016.

MALLET, Estêvão. Notas sobre o problema da chamada "decisão-surpresa". Revista da Faculdade de Direito, Universidade de São Paulo, v. 109, p. 389-414, jan./dez. 2014.

MARTINS, Eliezer Pereira. Segurança jurídica e certeza do direito em matéria disciplinar - aspectos atuais. Revista de Direito Administrativo, Rio de Janeiro, v. 230, p. 141-152, out./dez. 2002.

MARTINS, Ives Gandra da Silva; MENDES, Gilmar Ferreira. Controle concentrado de constitucionalidade: comentários à Lei n. 9.868, de 10-11-1999. $2^{\text {a }}$ ed. São Paulo: Saraiva, 2005.

MELO, Lígia Maria Silva de. Segurança jurídica: fundamento do Estado de Direito. A\&C - Revista de Direito Administrativo \& Constitucional, Belo Horizonte, ano 6, n. 25, p. 133-144, jul./set. 2006

MENDES, Conrado Hübner. Jurisprudência impressionista. Época, 14 set. 2018. Disponível em: <https://epoca.globo.com/conrado-hubner-mendes/jurisprudencia-impressionista-23066592>. Acesso em: 21 jul. 2019.

MENDES, Gilmar Ferreira. Jurisdição constitucional: o controle abstrato de normas no Brasil e na Alemanha. $4^{\text {a }}$ ed. São Paulo: Saraiva, 2004.

MENDES, Gilmar Ferreira; BRANCO, Paulo Gustavo Gonet. Curso de direito constitucional, 14a ed. rev. e atual. São Paulo: Saraiva Educação, 2019.

MOREIRA, Egon Bockmann; PEREIRA, Paula Pessoa. Art. 30 da LINDB - O dever público de incrementar a segurança jurídica. Revista de Direito Administrativo, Rio de Janeiro, Edição especial: Direito Público na Lei de Introdução às Normas de Direito Brasileiro - LINDB (Lei no 13.655/2018), p. 243-274, nov. 2018.

MOREIRA, José Carlos Barbosa. Breve notícia sobre a reforma do processo civil alemão. In: Temas de Direito Processual, Oitava Série, Rio de Janeiro: Saraiva, p. 199-210, 2004. 
NETO, Floriano de Azevedo Marques. Art. 23 da LINDB - O equilíbrio entre mudança e previsibilidade na hermenêutica jurídica. Revista de Direito Administrativo, Rio de Janeiro, Edição especial: Direito Público na Lei de Introdução às Normas de Direito Brasileiro - LINDB (Lei no 13.655/2018), p. 93-112, nov. 2018.

NUNES, Dierle José Coelho. Teoria do processo contemporâneo: por um processualismo constitucional democrático. Revista da Faculdade de Direito do Sul de Minas, p. 13-29, Edição Especial $-2018$.

PARGENDLER, Mariana; SALAMA, Bruno Meyerhof. Direito e consequência no Brasil: em busca de um discurso sobre o método. Revista de Direito Administrativo, Rio de Janeiro, v. 262, p. 95-144, jan./abr. 2013.

POGREBINSCHI, Thamy. Pragmatismo: teoria social e política. Rio de Janeiro: Relume Dumará, 2005.

POSNER, Richard A. Law, pragmatism, and democracy. Cambridge, Massachusetts; London, England: Harvard University Press, 2003.

SARLET, Ingo; MARINONI, Luiz Guilherme; MITIDIERO, Daniel. Curso de direito constitucional. 4 ed. ampl., incluindo novo capítulo sobre princípios fundamentais. São Paulo: Saraiva, 2015.

SCHUARTZ, Luis Fernando. Consequencialismo jurídico, racionalidade decisória e malandragem. Revista de Direito Administrativo, Atlas, p. 130-158, 2008.

SILVA, Almiro do Couto e. O princípio da segurança jurídica (proteção à confiança) no direito público brasileiro e o direito da administração pública de anular seus próprios atos administrativos: o prazo decadencial do art. 54 da lei do processo administrativo da União (Lei no 9.784/99). Revista de Direito Administrativo, Rio de Janeiro, v. 237, p. 271-315, jul./set. 2004.

THEODORO JÚNIOR, Humberto. Processo justo e contraditório dinâmico. Revista de Estudos Constitucionais, Hermenêutica e Teoria do Direito, v. 2, n. 1, p. 64-71, jan. a jun. 2010.

THEODORO JÚNIOR, Humberto; NUNES, Dierle José Coelho. Uma dimensão que urge reconhecer ao contraditório no direito brasileiro: sua aplicação como garantia de influência, de não surpresa e de aproveitamento da atividade processual. Revista de Processo, vol. 168, p. 107-141, fev. 2009, DTR\2009\156.

WANG, Daniel Wei Liang. Entre o consequenciachismo e o principiachismo, fico com a deferência. Jota, 20 set. 2018. Disponível em: <https://www.jota.info/paywall?redirect_to=//www. jota.info/opiniao-e-analise/artigos/entre-o-consequenciachismo-e-o-principiachismo-fico-com-a-deferencia-20092018>. Acesso em: 21 jul. 2019. 